Article

\title{
Cost-Benefit Analysis of Measures to Reduce Windstorm Impact in Pure Norway Spruce (Picea abies L. Karst.) Stands in Latvia
}

\author{
Valters Samariks ${ }^{1}{ }^{1}$, Oskars Krisans ${ }^{1}$, Janis Donis ${ }^{1}$, Ilze Silamikele ${ }^{2}$, Juris Katrevics ${ }^{1}$ \\ and Aris Jansons $1, *$ (D) \\ 1 Latvian State Forest Research Institute 'Silava', Rigas 111, LV-2169 Salaspils, Latvia; \\ valters.samariks@silava.lv (V.S.); oskars.krisans@silava.lv (O.K.); janis.donis@silava.lv (J.D.); \\ juris.katrevics@silava.lv (J.K.) \\ 2 Ministry of Agriculture Republic of Latvia, Republikas 2, LV-1981 Riga, Latvia; ilze.silamikele@zm.gov.lv \\ * Correspondence: aris.jansons@silava.lv; Tel.: +371-29-109-529
}

Received: 24 March 2020; Accepted: 19 May 2020; Published: 21 May 2020 updates

\begin{abstract}
Wind is one of the major natural forest disturbances in Europe, and reduces the total economic (including carbon sequestration) value of forests. The aim of this study was to assess the financial benefit of silvicultural measures in young, pure, planted Norway spruce stands by reduction in the impact of wind damage over the rotation period. The analyzed measures are promptly applied precommercial thinning and low-density planting with improved plant material. Spatial information on factors affecting wind damage-wind climate and soil—were gathered and combined with the local growth model and empirical data from tree pulling experiments in Latvia to assess the economic value loss due to wind damage over a rotation period. Timely precommercial thinning and lower-density planting with improved plant material would ensure a positive net present value with an interest rate of $3 \%$, using conservative estimates. The financial benefit is highest in windier (coastal) regions and for the planting, followed by moderate thinning. The results demonstrate that, even without changing the dominant tree species, a considerable reduction in wind-damage risk can be achieved.
\end{abstract}

Keywords: sparse stand; precommercial thinning; young stands; wind damage; natural disturbance

\section{Introduction}

Wind damage is a major disturbance in managed and natural forests in Europe, resulting in a drastic reduction in tree biomass and consequent loss of other forest ecosystem services, including economic and carbon sequestration value [1,2]. An increase in extreme weather events, directly or indirectly, causing large-scale damage in Europe's forests, has been observed in recent decades [2-8]. This trend is predicted to continue in the future [9], with windstorms being the primary cause for most stand damages with varying severity [10]. The impact of storms, especially in terms of damaged timber, is likely to rise in the future due to changes in storm tracks and the frequency and/or intensity of storms, and also due to changes in forest characteristics [11,12] and additional impacts of climate change. The supplementary impacts will vary depending on the geographical location, local soil and topographic conditions [13]. One of the impacts in hemiboreal and boreal forests, especially for forest stands growing on peat soil, is the reduction in frozen soil conditions during winter [14], leading to increased stand vulnerability to wind. Such an effect is especially significant for tree species that are more susceptible to wind damage (uprooting or breaking), like Norway spruce (Picea abies L. Karst.), because of its shallow root system and susceptibility to various other hazards (insects, diseases, drought) [15-17]. If no specific measures are taken, the current forest composition and proportion of this tree species is predicted to decrease notably by the end of this century [18]. 
Despite the available forest insurance for forest owners in some European countries [19], the change in tree species composition to more wind resistant species as a preventive measure has been suggested and sometimes even actively sought by government. For example, in Sweden, economic subsidies to change tree species (to species other than Norway spruce) have been provided after major storms [19-22]. In Latvia, support is also available for the restoration of stands affected (damaged) by natural disturbances $[19,23]$. However, after a decade, this support policy has not led to the desired result (change of tree species to more resilient types). Even in afforestation of wind-blown areas (where the impact of the storm is recent and can be clearly seen by the forest owner), no trend towards the use of more wind-resistant species (e.g., birch, pine) has been observed [20,21,24]. Such a result is partly attributed to the fact that owners focus on other, more immediate threats to young stands, like browsing damage, and partly to the estimated higher profitability of less wind-resistant alternatives [16,25]. Thus, it is essential to find and apply silvicultural measures that simultaneously addresses the immediate risks (like browsing), provide a desired financial outcome and increase stand wind resistance. One of such measures can be the thinning of young stands (precommercial thinning) [1,16,26-32].

Precommercial thinning has a positive effect on stand stability and increment in the long term $[1,16,31,32]$. It also reduces the need for commercial thinning (when the stand height noticeably exceeds $10 \mathrm{~m}$ ), which in itself is a significant factor, increasing the risk of wind damage for the following three-to-five years [16,33]. This is especially the case if heavy thinning (in terms of removed share from the total standing volume) is applied [18]. Trees that are suddenly open to the influence of the wind need time to adapt, in particular to develop root systems to ensure their stability [34]. The use of selected (improved by tree breeding) planting material ensures a gain in the volume of growth (increment) of around 10\%-25\%, or even higher in comparison to naturally regenerated stands [35,36]. A combination of improved planting material and lower initial spacing has a positive cumulative effect on the radial increment, and thus on the time when the target diameter, defined for the final harvest, can be reached $[29,30]$. Such a combination could reduce the cumulative probability of a windstorm striking the stand during the period when it is more prone to wind damage.

The economic implication of wind damage has been analyzed from different perspectives such as via an economic evaluation of dominant species change [37], management of pure and mixed stands [28], logging productivity and costs [38], and the impact of other forest ecosystem services (recreation, hunting) [39]. However, information on the potential effects of adaptation measures from an economic perspective in the context of forest policy decisions is still limited. Such information is needed to make efficient decisions for the allocation of public funds or use of other tools to increase overall forest adaptation (i.e., to reduce the impact of windstorms) over a long period on a national scale. The aim of this study was to assess the financial benefit of silvicultural measures in young, pure, planted Norway spruce stands by a reduction in the impact of wind damage over the rotation period. Specifically, we tested whether additional precommercial thinning (leading to two different stand densities) or low-density stand establishment with selected (improved) planting material ensured financial profitability (indicated by net present value), given the influence on the reduction in wind damage probability, over 50- and 80-year timespans.

\section{Materials and Methods}

Methods to reduce financial impact of wind damages were modelled on an area (per ha) basis for the hemiboral vegetation zone [40], based on the example of Latvia $\left(55^{\circ} 60^{\prime}-58^{\circ} 10^{\prime} \mathrm{N}\right.$, $\left.20^{\circ} 70^{\prime}-28^{\circ} 50^{\prime} \mathrm{E}\right)$. This country, like other territories in the Baltic Sea region within the same vegetation zone, is characterized by a flat relief [41] and a notable proportion of land (52\%) covered by forests [42]. Norway spruce is an economically significant, widespread tree species in this region (e.g., in Latvia its stands cover $19 \%$ of the forest area [43]), regenerated almost exclusively by planting, typically on good quality (fertile, fresh or drained) soils. Data (spatial allocation of different forest types) from the State Forest Service (year 2005) [44] and historic agriculture soil inventories [45] were combined and converted to soil types, relevant for the wind stability of trees [46]. The results demonstrate that soils 
suitable for Norway spruce and with different properties in relation to wind stability are located across Latvia (Figure 1).

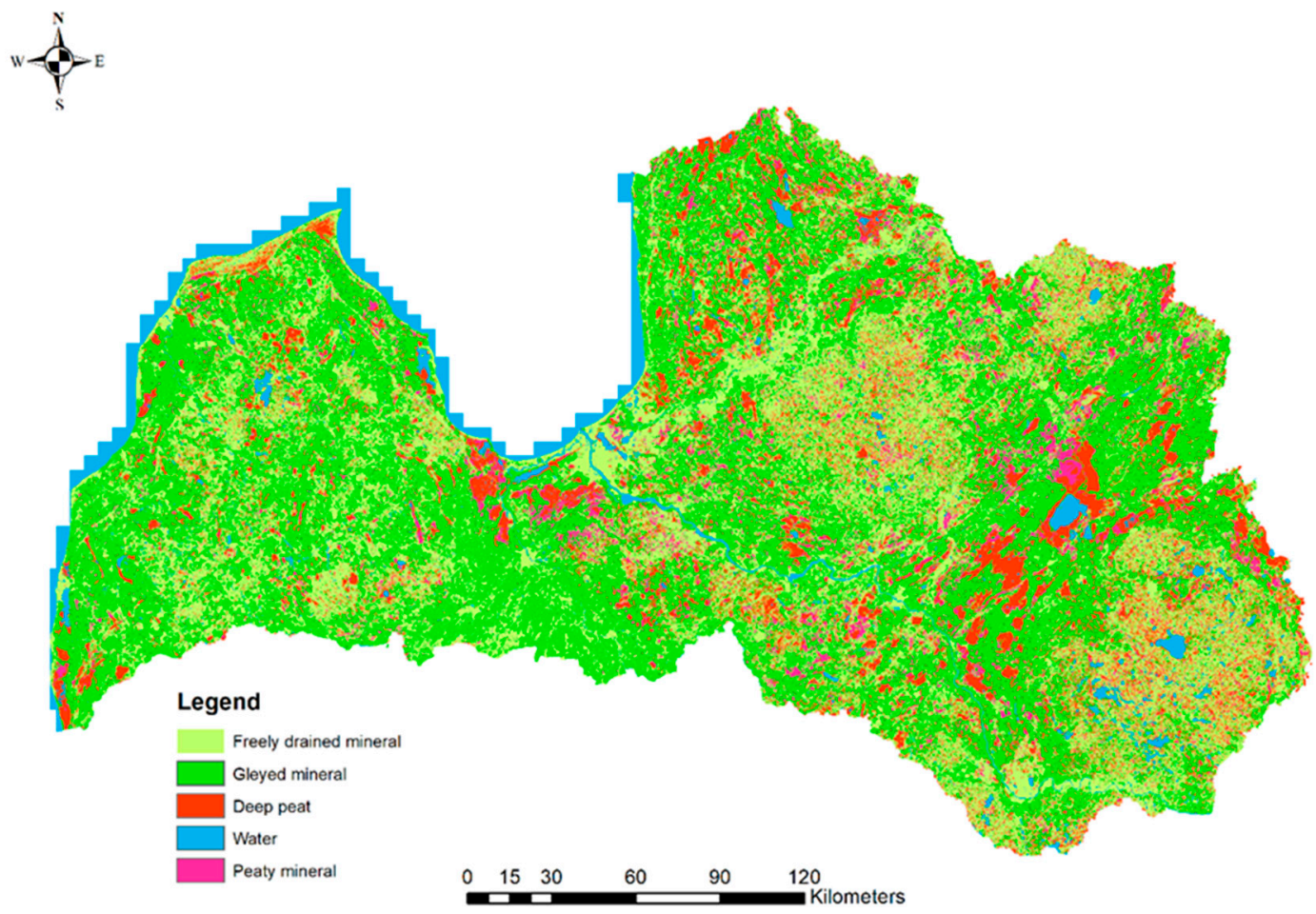

Figure 1. Allocation of soil type groups in the territory of Latvia.

The financial impact of wind damage depends on the probability of its occurrence and the amount of damaged timber. The probability of occurrence in the mechanistic model is determined by soil, wind climate, forest (landscape and stand) as well as tree parameters [16]. Freely drained mineral soils and site indices (SI) 32 are used as the bases for the study, since most spruce stands would have SI values of 36 or 32 (34\% and 39\% from all spruce dominated stands, respectively). The wind climate was characterized by Weibull distribution A parameter values, as required by the conceptual framework of tree wind resistance assessment by Quine [47]. A is the Weibull distribution scale parameter in $\mathrm{m}$ $\mathrm{s}^{-1}$, a measure for the characteristic wind speed of the distribution-it is proportional to the mean wind speed. The values of this parameter, calculated based on fundamental wind speed and data from long-term meteorological observations from the Latvian Environment, Geology and Meteorology Centre, range from 3.3 to 6.7 (Figure 2). The highest values primarily are in the western part of Latvia, near the Baltic Sea. For this region (hereafter referred to as "coastal"), a Weibull A parameter value of 5.0 was used and for the rest of the territory (hereafter referred to as "inland") a value of 4.2 was used.

Both stands without new open edges (e.g., due to the clear cutting of neighbouring stands) and the short-term impact of commercial thinning were not included in the calculations, thus representing a conservative estimate of the probability of the occurrence of wind damage [16]. Tree and stand parameters at a certain age, depending on the selected management regime, were calculated by local growth models [48]. Empirical data, obtained in tree pulling experiments in Latvia [49,50], including the volume of the root-soil plate [51], relative crown height, slenderness, and conceptual framework as defined by Quine [47], were used to determine the wind speed in gusts (critical wind speed) needed for a tree with a certain dimension to be snapped or uprooted. The five-year cumulative probability of the occurrence of critical wind speed (for the average tree in the stand with certain management regime) was assumed to be equal to the proportion of damaged area where salvage-logging is required. For example, if the cumulative probability of the occurrence of critical wind speed in a 5-year period is $4 \%$, then it was assumed that, in this 5-year period, salvage logging would be carried out in $4 \%$ 
of the area. In terms of salvage-logging, $10 \%$ of the most valuable assortments were assumed to be damaged and classified as firewood; it also resulted in higher logging costs (Table 1) and smaller dimensions of harvested trees. The volume of the wood assortment, obtained in any type of harvesting, was determined based solely on the dimensions of the trees in the stand in accordance with the equation developed by Ozolin,š [52] and modified by Donis [53].

The costs in the financial calculations were based on Central Statistical Bureau (CSB) [54] information (Table 1).

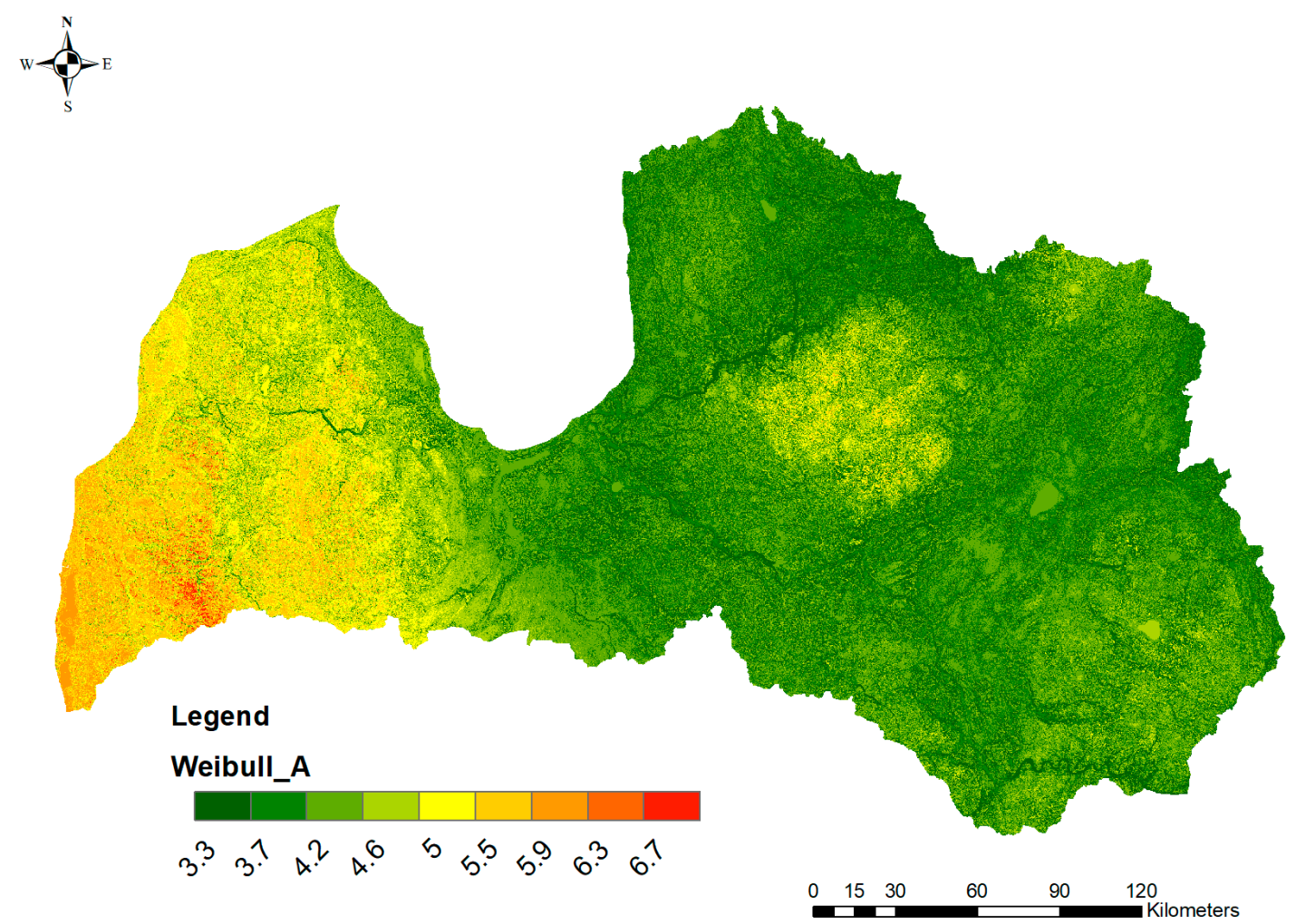

Figure 2. Wind climate: Weibull distribution parameter A (characteristic wind speed) values.

Table 1. Forest management operations and their costs.

\begin{tabular}{|c|c|c|c|}
\hline Management Operation & & Costs & \\
\hline Soil preparation and planting & & $160 \mathrm{EUR} \mathrm{ha}^{-1}$ & \\
\hline Plants & & 150 EUR 1000 plants & \\
\hline Planting & & 85 EUR 1000 plants & \\
\hline Tending & & 110 EUR ha $^{-1}$ & \\
\hline Pre-commercial thinning & & 124 EUR ha $^{-1}$ & \\
\hline Logging: & Regeneration cut, EUR m ${ }^{-3}$ & Thinning, EUR $\mathrm{m}^{-3}$ & Salvage-logging, EUR $\mathrm{m}^{-3}$ \\
\hline Assortment preparation (harvesting) & 5.70 & 9.39 & 9.85 \\
\hline Timber extraction (delivery) & 4.94 & 6.14 & $4.94-6.14$ \\
\hline Timber transportation (forwarding) & 5.90 & 6.07 & $5.90-6.07$ \\
\hline
\end{tabular}

Additional costs included the real estate tax of $5 \mathrm{EUR} \mathrm{ha}^{-1}$ year $^{-1}$ and management (administration) costs of $10 \mathrm{EUR} \mathrm{ha}^{-1}$ year $^{-1}$. Income from the harvest (planned and salvage-logging) was based on the volume and prices of the assortments (Table 2). 
Table 2. Assortment and their price.

\begin{tabular}{cccc}
\hline Assortment & Minimum Top Diameter, $\mathbf{c m}$ & Minimum Length, $\mathbf{~}$ & Price, EUR $\mathbf{~ m}^{\mathbf{3}}$ \\
\hline Sawlogs I & $>28$ & 3.6 & 71 \\
Sawlogs II & $18.1-28$ & 3.6 & 68 \\
Sawlogs III & $14.1-18$ & 3.6 & 62 \\
Pulpwood & $10.1-14$ & 3 & 28 \\
Firewood & $6-10$ & 3 & 26 \\
\hline
\end{tabular}

Possibilities to reduce the financial impact of wind damages in planted pure Norway spruce stands were modelled on an area (per ha) basis, evaluating two potential silvicultural measures:

I. The additional (second) precommercial thinning of young (height is $4-6 \mathrm{~m}$ ) stands to a low density (600-900 spruces ha ${ }^{-1}$ ) or moderate density (1000-1300 spruces ha $\left.{ }^{-1}\right)$. To evaluate the influence of this precommercial thinning, a comparison was made with un-thinned (density 1400-1700 spruces ha ${ }^{-1}$ ) stands (control). The financial value of these stands over 80 years was modelled. To obtain the range of potential outcomes, and thus to obtain a mean result and a measure of variance $( \pm 95 \%$ confidence interval), for each of the alternatives, we used four densities after precommercial thinning (i.e., for low density $-600,700,800$ and 900 spruces ha $^{-1}$ ) and, for each of these densities, three different commercial thinning regimes (when the stand age was 20-55 years old) applied: 1) thinning carried out, when the relative stand density reaches 0.95 and it is then reduced to $0.7 ; 2$ ) thinning is done when the relative stand density reaches 0.95 and it is then reduced to 0.45 ; and 3) thinning is done when the relative stand density reaches 0.95 , and in the first commercial thinning it is reduced to 0.45 and in the second thinning to 0.7 . Thus, the result of each of the three precommercial thinning alternatives (low density, moderate density and un-thinned) was a mean from twelve model runs (four densities $x$ three commercial thinning regimes). Commercial thinning time and the amount of harvested assortments in each of the model runs summarised in Supplementary Table S1. In all alternatives, the initial planting density was 2000 spruce $\mathrm{ha}^{-1}$, followed by two tendings (weed controls) and one pre-commercial thinning. Thus, the differences in costs arise from a single (second) precommercial thinning, which was either carried out (to low or moderate density) or not (un-thinned);

II. The establishment of lower-density (1000 spruces ha $\left.{ }^{-1}\right)$ stands with selected (improved) planting material. To evaluate the influence of this measure, it was compared to standard density (2000 spruces $\mathrm{ha}^{-1}$ ) plantation, established using unimproved plant material (control). The same initial costs were used for both alternatives, assuming that improved plants (progenies of second generation seed orchards, demonstrating $20 \%$ higher volume increment [36]) would be more expensive (and thus compensate for extra costs of 1000 unimproved plants ha ${ }^{-1}$ needed in control). In both alternatives, two tendings (weed controls) and one pre-commercial thinning was planned, leading to 600-900 spruces ha ${ }^{-1}$ (assuming some natural mortality) for low-density plantation and, with extra precommercial thinning (no costs assessed), to 1000-1300 spruces ha ${ }^{-1}$ in the control. To model further stand development, the three abovementioned (I) different commercial thinning regimes were applied. Therefore, this leads to twelve model runs (four different densities at the time of second precommercial thinning in control alternative $x$ three commercial thinning regimes) for each alternative to obtain the mean and the variance of the outcomes.

The financial value of each measure was expressed as the net present value (NPV) with a 3\% discount rate:

$$
N P V=\frac{R}{(1+i)^{t}}
$$

where $R=$ net cash flow, $i=$ discount rate ( $3 \%)$, and $t=$ number of time periods.

The results of the model runs and calculated NPVs were used to determine the statistical significance of the differences between the alternatives, using a single-factor analysis of variance. 


\section{Results}

Net present values $(r=3 \%)$ of planted Norway spruce stands without consideration of wind damage, independent of precommercial thinning alternatives (to low or moderate density or un-thinned), reached their peak on average at the age of 65 years, when the highest NPV was $846 \pm 94.2 \mathrm{EUR} \mathrm{ha}^{-1}$ (Figure 3). As the stands aged, all analysed precommercial thinning alternatives followed the same trend of gradually decreasing financial value. The highest value was for un-thinned (density 1400-1700 spruces ha ${ }^{-1}$ ) and moderately thinned (1000-1300 spruces ha ${ }^{-1}$ ) stands. The differences between these alternatives and the one with the lowest density after precommercial thinning (600-900 spruces ha ${ }^{-1}$ ) were significant most of the time, except at the age of 50-65 years. The average difference in NPV in an undamaged stand and a stand that needs to be salvage-logged due to wind damage increased with time, reaching its peak at the age of 50-55 years.

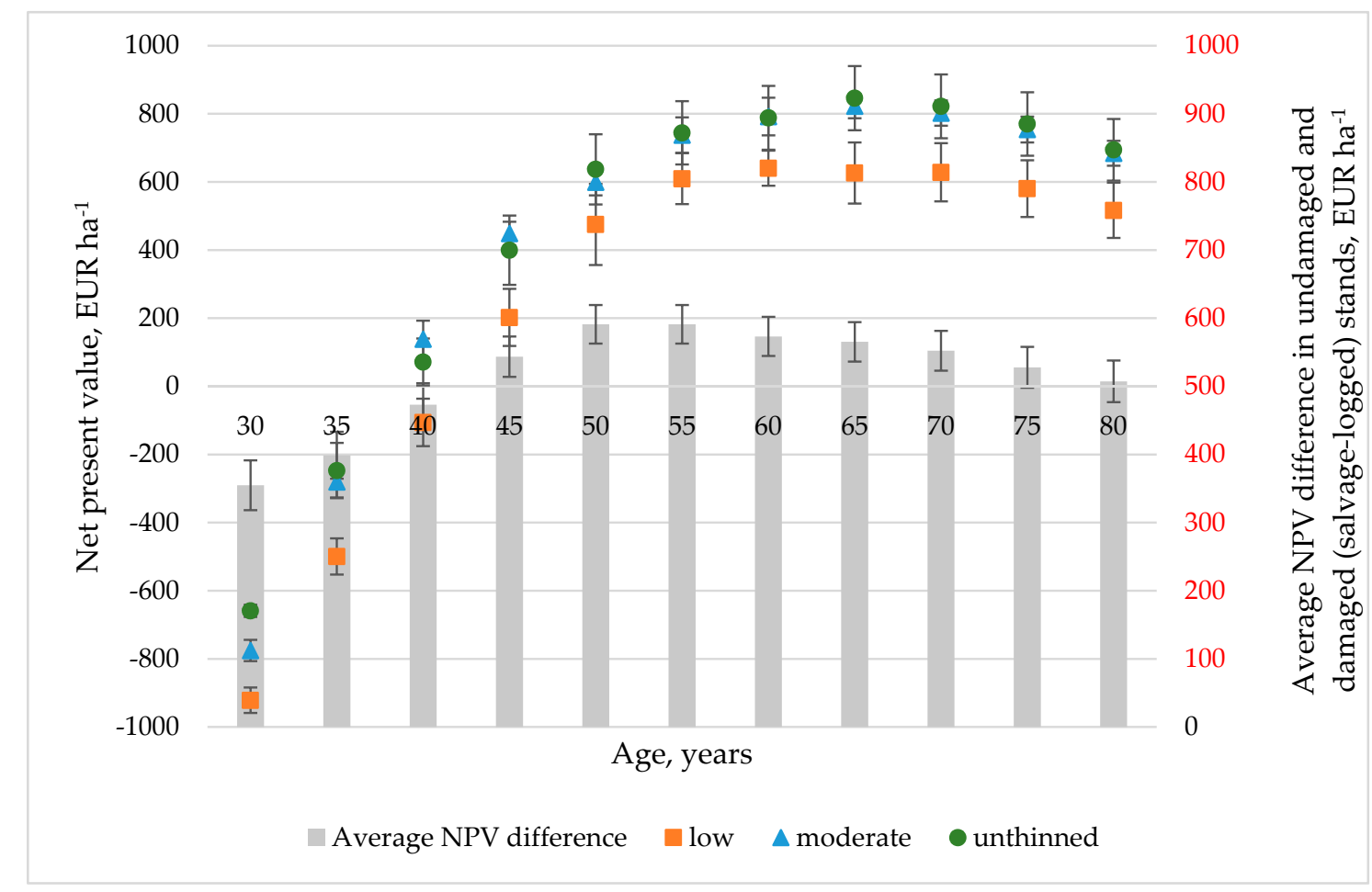

Figure 3. Net present value (NPV) of three different thinning regimes (to low and moderate density and un-thinned) in undamaged stands at different ages. Points represent NPV of each thinning regime, bars represent NPV difference between undamaged and damaged stands. Whiskers denote confidence interval.

NPVs of the planted Norway spruce stands with the consideration of wind damage were higher for stands where precommercial thinning (to low or moderate density) was carried out, due to faster diameter growth and lower damage probability. The differences were higher in coastal regions with higher wind speeds (Weibull distribution A parameter values) than inland. However, this was mostly dependent on the precommercial thinning intensity: at the age of 50-60 years, stands with moderate thinning had higher NPVs by $98.1 \pm 3.9 \mathrm{EUR} \mathrm{ha}^{-1}$ and 122.4 $\pm 20.3 \mathrm{EUR} \mathrm{ha}^{-1}$ than un-thinned stands (in coastal and inland wind climate, respectively), though the difference between stands, thinned to low density and un-thinned, was notably smaller: $17.7 \pm 5.5 \mathrm{EUR} \mathrm{ha}^{-1}$ and $37.8 \pm 7.5 \mathrm{EUR}^{\mathrm{h}} \mathrm{Ea}^{-1}$, respectively (Figure 4).

Similar NPV differences between precommercial thinning alternatives and wind climates were also found at the age of 70-80 years: moderate thinning ensured a $109 \pm 3.2 \mathrm{EUR} \mathrm{ha}^{-1}$ to $119 \pm 5.4 \mathrm{EUR}^{\mathrm{h}} \mathrm{ha}^{-1}$ 
higher value than un-thinned stands and those thinned to a low density-by $20 \pm 4.2 \mathrm{EUR}^{-1}$ to $68 \pm 24.4$ EUR ha ${ }^{-1}$ - in inland and coastal wind climates, respectively.

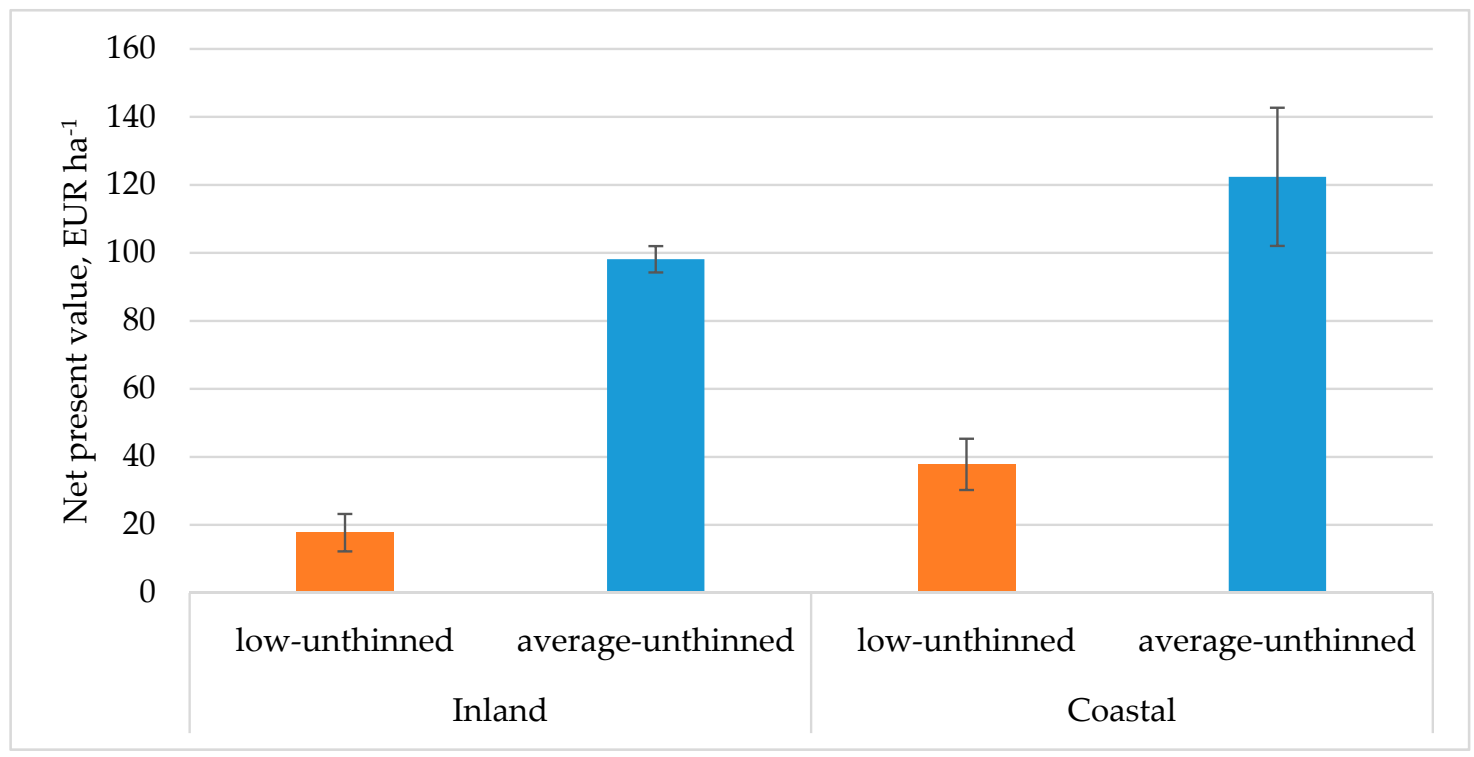

Figure 4. Difference in NPV of two different thinning intensities (to low and moderate density) and control in two wind-climate regions (coastal and inland) at the age of 50-60 years. Whiskers denote confidence interval of NPV.

The influence of different initial planting densities and tree improvements on the NPV of the planted Norway spruce stands with the consideration of wind damage was even more pronounced than the influence of precommercial thinning (Figure 5). Low-density stands (1000 trees ha ${ }^{-1}$, regenerated with improved planting material) at the age of 50-60 years had a $166 \pm 40 \mathrm{EUR} \mathrm{ha}^{-1}$ to $297 \pm 39 \mathrm{EUR} \mathrm{ha}^{-1}$ (in inland and coastal wind climate, respectively) higher NPV than the control stand (2000 trees ha ${ }^{-1}$, regenerated with unimproved planting material). At the age of 70-80 years, the values were slightly lower, $124 \pm 33 \mathrm{EUR} \mathrm{ha}^{-1}$ and $276 \pm 32 \mathrm{EUR} \mathrm{ha}^{-1}$, respectively, but the differences were similar.

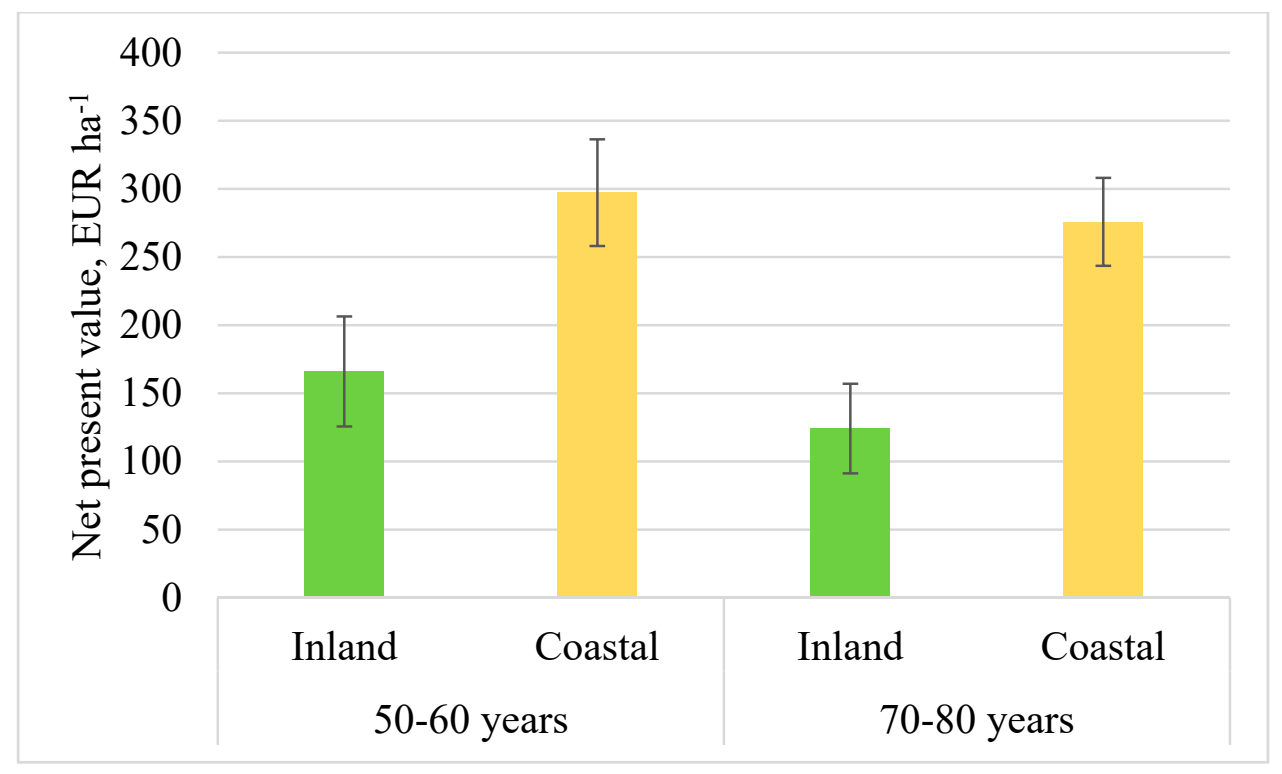

Figure 5. Differences in NPV between low-density stands, regenerated with improved material in low density and unimproved with standard density at the age of 50-70 years and 70-80 years in two different wind climates. Whiskers denote confidence interval. 


\section{Discussion}

Quantitative information on differences in wind climate is relevant for strategical planning and policy decisions at the country scale, providing incentives to reduce the overall economic impact of damage. Such information is also important to the forest owner for the planning of forest management (from selection of tree species, to thinning schedule, to length of rotation period) in order to reduce wind damage probability to an acceptable level $[1,16,27]$. Thus, at both a countrywide and property scale, it is necessary to balance an economic assessment of value risk against the potential gain from timber production. Spatial data from this study (Figures 1 and 2) provides the basic information for such an assessment.

Strategic planning for reduced tree damage is no longer of importance solely for the forest sector. Since forests and peatlands are, at present, the only two true large-scale carbon sinks, policies related to climate change mitigation (and EU targets in this respect) also need to consider the damage risk, which is predicted to have an increasing negative effect on carbon balance $[2,55,56]$. Thus, a practically applicable option for risk reduction is needed. Such options (low-density stands and young stand thinning) were assessed in our study, growing on freely drained mineral soils with the highest site indices (32) for each measure, and not considering the change in dominant tree species.

Although the area subjected to precommercial thinning in private forests has almost doubled during the last decade in Latvia, there is still a considerable amount of un-thinned young stands on fertile soils [57]. A similar situation can be observed in numerous countries in Europe [58], due to the decreasing interest and profitability of forestry as an economic activity for numerous reasons. To increase the area of thinning of young stands, considerable investments are required (Table 1). The study results showed that in undamaged stands where three different thinning intensities are applied, the highest NPV is found for un-thinned stands. However, in un-thinned stands, the wind damage probability is the highest and it can cause major financial losses in Norway spruce stands (Figure 3). Wind damage probability increases with forest stand age and our study results are in accordance with previous studies [26,59]. The calculations showed that different thinning intensities increase the financial value of the stand in comparison to un-thinned stands and the most productive thinning regime is moderate thinning (Figure 4). Thinning to low density (heavy thinning) increases the risk of wind damage in comparison to moderate thinning, because the stands are more exposed to a higher wind load, to which they have not been adapted [22,60]. Income at the end of the rotation period is significantly higher in coastal wind regions than inland, even with wind damage. A final harvest at 80 years of age can achieve slightly higher values than a final harvest at 50 years of age; however, a significant difference was only seen in the inland wind region with a moderate thinning intensity.

Forest stand replacement also requires high (and increasing) investment, and therefore self-regeneration is used in most of the areas in Europe [61]. There is a similar tendency in Latvia, but even so, the annual planting area in private forests has increased over the last four years [57], and seedling demand currently exceeds availability [62]. The implementation of low-density stands would require changes in the legislation; the associated costs are not included in the assessment, since it is considered that reduced plant material costs would compensate for them. The calculations of our study show that, in all cases, originally established low-density stands reach significantly higher NPV (Figures 4 and 5) in comparison to other silvicultural measures applied. Even with windstorm damage, the financial benefit is higher than in originally established high density stands (2000 trees ha $\left.{ }^{-1}\right)$ with different precommercial thinning intensities. Low-density stands reach larger tree dimensions faster and tend to have better individual tree stability than high-density stands $[1,29,63]$. Similarly, as in thinned stands, higher NPVs between low-density stands were found in coastal regions (Figure 5). A final harvest at 50 years is more profitable than at the age of 80 years; however, the differences are not statistically significant. Additionally, in such stands, the admixture of other tree species can be expected. The admixture of other tree species may reduce (at least temporarily) the risk of wind damage [22,64,65]. 
Wind damage-related expenses in our analysis are the higher costs of salvage-logging (by 10-30\% in comparison to logging of undamaged areas [38]) and a 10\% reduction in the amount of the most valuable assortment, due to timber damage such as snapping and stem cracks. These estimates are rather conservative; more damage to assortments can be predicted [66] and, in the case of large-scale storms, a lack of available logging teams can raise the price of this operation even more. Moreover, storm damage creates a peak in timber supply, thus reducing the price [11]. However, this effect would depend on the scale of the storm and the overall economic situation and is difficult to predict. In our study, additional positive effects of the proposed measures on the wind stability of the stands (e.g., from early adaptation of trees to stronger winds or reduction in the need for commercial thinning) were not considered. The potential to use only optimal soils (replacing other species) was also not considered. Thus, our estimate is conservative. Further research could be applied for different soil types, tree species or even the retention of trees after regeneration cutting.

\section{Conclusions}

The study was carried out to provide actual information about and a financial evaluation of silvicultural measures to reduce wind damage risk. Wind climate and soil type maps demonstrate noticeable differences in vulnerability, even within a relatively small and flat area such as Latvia, and are important tools for forest policy and strategic planning.

Even without changing the dominant tree species, a considerable reduction in risk can be achieved with forest management. Timely precommercial thinning and lower-density planting, using conservative estimates, ensure positive NPVs with an interest rate of 3\%. Low-density stands reach higher NPVs in all wind regions in comparison to precommercial thinning and final felling at 50 years is more profitable than at the currently defined 80-year rotation period. The negative financial impact of wind damage can be reduced by establishing stands with wider initial spacing (lower density) and reducing the length of the rotation period (changing the time of the final harvest by the target diameter).

Supplementary Materials: The following are available online at http://www.mdpi.com/1999-4907/11/5/576/s1, Table S1: Commercial thinning schedule (assortment volume, $\mathrm{m}^{3} \mathrm{ha}^{-1}$ ) in stands with different initial densities (trees $\mathrm{ha}^{-1}$ ) and thinning criteria: KKC1—thinning is done when the relative stand density reaches 0.95 and is then reduced to $0.7 ; \mathrm{KKC} 2$ - thinning is done when the relative stand density reaches 0.95 and is then reduced to 0.45 ; KKC3 - thinning is done when the relative stand density reaches 0.95 , and in the first commercial thinning it is reduced to 0.45 and in the second thinning to 0.7 .

Author Contributions: Conceptualization, J.D. and O.K.; methodology, J.D., O.K. and I.S.; formal analysis, A.J. and J.D.; data curation, J.D. O.K. and A.J.; writing-original draft preparation, V.S. and A.J.; writing-review and editing, O.K., I.S. and J.K.; project administration, A.J. All authors have read and agreed to the published version of the manuscript.

Funding: This study was funded by the European Regional Development Fund project Development of decision support tool for prognosis of storm damages in forest stands on peat soils (No. 1.1.1.1/16/A/260).

Acknowledgments: We acknowledge the State Forest Service for forest type classification and forest land type data for research purposes. The authors acknowledge the Ministry of Environmental Protection and Regional Development of the Republic of Latvia for funding during the development of initial ideas for the assessment. We acknowledge the Latvian Environment, Geology and Meteorology Centre for the meteorological data. We acknowledge the input of the reviewers, who helped to significantly improve the manuscript.

Conflicts of Interest: The authors declare no conflict of interest.

\section{References}

1. Gardiner, B.; Quine, C.P. Management of forests to reduce the risk of abiotic damage-A review with particular reference to the effects of strong winds. Forest Ecol. Manag. 2000, 135, 261-277. [CrossRef]

2. Nabuurs, G.J.; Lindner, M.; Verkerk, P.J.; Gunia, K.; Deda, P.; Michalak, R.; Grassi, G. First signs of carbon sink saturation in European forest biomass. Nat. Clim. Chang. 2013, 3, 792-796. [CrossRef]

3. Kron, W.; Löw, P.; Kundzewicz, Z.W. Changes in risk of extreme weather events in Europe. Environ. Sci. Policy 2019, 100, 74-83. [CrossRef] 
4. EASAC. Extreme Weather Events in Europe. 2018. Available online: https://easac.eu/fileadmin/PDF_s/ reports_statements/Extreme_Weather/EASAC_Statement_Extreme_Weather_Events_March_2018_FINAL. pdf (accessed on 7 March 2020).

5. Stott, P.A.; Christidis, N.; Otto, F.E.L.; Sun, Y.; Vanderlinden, J.P.; van Oldenborgh, G.J.; Zwiers, F.W. Attribution of extreme weather and climate-related events. Wiley Interdiscip. Rev. Clim. Chang. 2016, 7, $23-41$. [CrossRef] [PubMed]

6. Coumou, D.; Rahmstorf, S. A decade of weather extremes. Nat. Clim. Chang. 2012, 2, 491-496. [CrossRef]

7. Frank, D.; Reichstein, M.; Bahn, M.; Thonicke, K.; Frank, D.; Mahecha, M.D.; Zscheischler, J. Effects of climate extremes on the terrestrial carbon cycle: Concepts, processes and potential future impacts. Glob. Chang. Biol. 2015, 21, 2861-2880. [CrossRef]

8. Zhang, T.; Niinemets, U.; Sheffield, J.; Lichstein, W.J. Shifts in tree functional composition amplify the response of forest biomass to climate. Nature 2018, 556, 99-102. [CrossRef] [PubMed]

9. IPCC. Summary for policymakers. In Climate Change and Land: An IPCC Special Report on Climate Change, Desertification, Land Degradation, Sustainable Land Management, Food Security, and Greenhouse Gas Fluxes in Terrestrial Ecosystems; Shukla, P.R., Skea, J., Calvo Buendia, E., Masson-Delmotte, V., Pörtner, H.-O., Roberts, D.C., Malley, J., Eds.; IPCC: Geneva, Switzerland, 2019.

10. Seidl, R.; Thom, D.; Kautz, M.; Martín-Benito, D.; Peltoniemi, M.; Vacchiano, G.; Reyer, C. Forest disturbances under climate change. Nat. Clim. Chang. 2017, 7, 395-402. [CrossRef]

11. Gardiner, B.; Schuck, A.R.T.; Schelhaas, M.J.; Orazio, C.; Blennow, K.; Nicoll, B. Living with Storm Damage to Forests: What Science can Tell Us, 3rd ed.; European Forest Institute: Joensuu, Finland, 2013; p. 133.

12. Motta, R.; Ascoli, D.; Corona, P.; Marchetti, M.; Vacchiano, G. Silviculture and wind damages, the storm "Vaia". Forest@- Rivista di Selvic. ed Ecol. Forest 2018, 15, 94-98. (In Italian with English summary). [CrossRef]

13. Xi, W.; Peet, R.K.; Decoster, J.K.; Urban, D.L. Tree damage risk factors associated with large, infrequent wind disturbances of Carolina forests. Int. J. For. Res. 2008, 81, 317-334. [CrossRef]

14. Laapas, M.; Lehtonen, I.; Venäläinen, A.; Peltola, H.M. The 10-year return levels of maximum wind speeds under frozen and unfrozen soil forest conditions in Finland. Climate 2019, 7, 62. [CrossRef]

15. Caudullo, G.; Tinner, W.; de Rigo, D. Picea abies in Europe: Distribution, habitat, usage and threats. In European Atlas of Forest Tree Species; San-Miguel-Ayanz, J., de Rigo, D., Caudullo, G., Houston Durrant, T., Mauri, A., Eds.; Publication Office of the European Union Luxembourg: Luxembourg, 2016; pp. 114-116.

16. Donis, J.; Kitenberga, M.; Šnepsts, G.; Dubrovskis, E.; Jansons, Ā. Factors affecting windstorm damage at the stand level in hemiboreal forests in Latvia: Case study of 2005 winter storm. Silva Fenn. 2018, 52. [CrossRef]

17. Šnepsts, G.; Donis, J.; Strēlnieks, K.; Krišāns, O.; Desaine, I.; Adamovičs, A. Post-storm regeneration of Norway spruce. In Proceedings of the 25th Annual International Scientific Conference “Research for Rural Development 2019", Jelgava, Latvia, 17-19 May 2019; pp. 71-75. [CrossRef]

18. Peltola, H.; Ikonen, V.P.; Gregow, H.; Strandman, H.; Kilpeläinen, A.; Venäläinen, A.; Kellomäki, S. Impacts of climate change on timber production and regional risks of win-induced damage to forests in Finland. For. Ecol. Manag. 2010, 260, 833-845. [CrossRef]

19. Destructive Storms in European Forests: Past and Forthcoming Impacts. Available online: https://ec.europa. eu/environment/forests/pdf/STORMS\%20Final_Report.pdf (accessed on 5 February 2020).

20. Andersson, E.; Carina, E.; Keskitalo, H.; Bergstén, S. In the eye of the storm: Adaptation logics of forest owners in management and planning in Swedish areas. Scand. J. For. Res. 2018, 33, 800-808. [CrossRef]

21. Valinger, E.; Kempe, G.; Fridman, J. Forest management and forest state in southern Sweden before and after the impact of storm Gudrun in the winter of 2005. Scand. J. For. Res. 2014, 29, 466-472. [CrossRef]

22. Valinger, E.; Fridman, J. Factors affecting the probability of windthrow at stand level as a result of Gudrun winter storm in southern Sweden. For. Ecol. Manag. 2011, 262, 398-403. [CrossRef]

23. Rural Support Service. Restoration of Forest Stands Destroyed by Forest Fires and Natural Disasters. Available online: http://www.lad.gov.lv/lv/atbalsta-veidi/projekti-un-investicijas/atbalsta-pasakumi/8-4meza-ugunsgrekos-un-dabas-katastrofas-iznicinatu-mezaudzu-atjaunosana-231 (accessed on 5 February 2020). (In Latvian)

24. Dubrovskis, E.; Jansone, B.; Kapostins, R.; Racenis, E.; Sisenis, L. Influence of wind-storm on forest composition: Case study in north- western Latvia. In Proceedings of the SGEM2018 Vienna GREEN Conference, Vienna, Austria, 3-6 December 2018; Volume 18, pp. 703-710. [CrossRef] 
25. Lodin, I. Choice of Tree Species in the Aftermath of Two Major Storms-A Qualitative Study of Private Forest Owners in Southern Sweden. Master's Thesis, Swedish University of Agriculture, Uppsala, Sweden, 2016.

26. Suvanto, S.; Henttonen, H.M.; Nöjd, P.; Mäkinen, H. Forest susceptibility to storm damage is affected by similar factors regardless of storm type: Comparison of thunder storms and autumn extra-tropical cyclones in Finland. For. Ecol. Manag. 2016, 381, 17-28. [CrossRef]

27. Suvanto, S.; Peltoniemi, M.; Tuominen, S.; Strandstöm, M.; Lehtonen, A. High-resolution mapping of forest vulnerability to wind for disturbance-aware forestry. For. Ecol. Manag. 2019, 453, 117-159. [CrossRef]

28. Zell, J.; Hanewinkel, M. How treatment, storm events and changed climate affect productivity of temperate forests in SW Germany. Reg. Environ. Chang. 2015, 15, 1531-1542. [CrossRef]

29. Katrevičs, J.; Džerina, B.; Neimane, U.; Desaine, I.; Bigača, Z.; Jansons, Ā. Production and profitability of low density Norway spruce (Picea abies (L.) Karst.) plantation at 50 years of age: Case study from eastern Latvia. Agron. Res. 2018, 16, 113-121. [CrossRef]

30. Zeltiňš, P.; Matisons, R.; Gailis, A.; Jansons, J.; Katrevičs, J.; Jansons, Ā. Genetic parameters of growth traits and stem quality of silver birch in a low-density clonal plantation. Forests 2018, 9, 52. [CrossRef]

31. Brüchert, F.; Becker, G.; Speck, T. The mechanics of Norway sprcuce [Picea abies (L.) Karst.]: Mechanical properties of standing trees from different thinning regimes. For. Ecol. Manag. 2000, 135, 45-62. [CrossRef]

32. Slodicak, M.; Novak, J. Silvicultural measures to increase the mechanical stability of pure secondary Norway spruce stands before conversion. For. Ecol. Manag. 2006, 224, 252-257. [CrossRef]

33. Gardiner, B.; Blennow, K.; Carnus, J.-M.; Fleischer, M.; Ingemarson, F.; Landmann, G. Destructive Storms in European Forests: Past and Forthcoming Impacts; Final report to DG Environment (07.0307/2009/SI2.540092/ETU/B.1); EFI: Helsinki, Finland, 2010; p. 113.

34. Krause, C.; Lemay, A.; Tremblay, S.; Ruel, J.C.; Plourde, P.Y. How does the root system inhibit windthrow in thinned black spruce sites in the boreal forests? Trees 2014, 28, 1723-1735. [CrossRef]

35. Jansson, G.; Danusevičius, D.; Grotehusman, H.; Kowalczyk, J.; Krajmerova, D.; Skrøppa, T.; Wolf, H. Norway spruce. In Forest Tree Breeding in Europe. Managing Forest Ecosystems; Picea abies, L., Karst, H., Pâques, L., Eds.; Springer: Dordrecht, The Netherlands, 2013; Volume 25, pp. 123-176. [CrossRef]

36. Jansson, G.; Hansen, J.K.; Haapanen, M.; Kvaalen, H.; Steffenrem, A. The genetic and economic gains from forest tree breeding programmes in Scandinavia and Finland. Scand. J. For. Res. 2017, 32, 273-286. [CrossRef]

37. Brunette, M.; Costa, S.; Lecocq, F. Economics of species change subject to risk of climate change and increasing information: A (quasi-)option value analysis. Ann. For. Sci. 2014, 71, 279-290. [CrossRef]

38. Kärhä, K.; Anttonen, T.; Poikela, A.; Palander, T.; Laurén, A.; Peltola, H.; Nuutinen, Y. Evaluation of salvage logging productivity and costs in windthrown Norway Spruce- dominated forests. Forests 2018, 9, 280. [CrossRef]

39. Andersson, M.; Kellomäki, S.; Gardiner, B.; Blennow, K. Life-style services and yield from south-Swedish forests adaptively managed against the risk of wind damage: A simulation study. Reg. Environ. Chang. 2014, 15, 1489-1500. [CrossRef]

40. Ahti, T.; Hämet-ahti, L.; Jalas, J.; Annales, S.; Fennici, B. Vegetation zones and their sections in northwestern Europe. Ann. Bot. Fenn. 1968, 5, 169-211.

41. Spalvins, A.; Slangens, J.; Lace, I.; Aleksans, O.; Krauklis, K. Regional hydrogeological model of Latvia for management of its groundwater resources. In Proceedings of the International Conference on Applied Information and Communication Technologies (AICT2012), Riga Technical University, Latvia, 24-26 April 2012; pp. 135-144.

42. NFI. National Forest Monitoring. 2018. Available online: http://www.silava.lv/petijumi/nacionlais-meamonitorings.aspx (accessed on 10 February 2020). (In Latvian).

43. Ministry of Agriculture. Latvian Forest Sector in Facts and Figures 2019; Zal̄ās mājas: Riga, Latvia, 2019 ; p. 53.

44. State Forest Service. Publiskais Pārskats, 2005 Annual Report. Available online: https://www.zm.gov.lv/ public/files/CMS_Static_Page_Doc/00/00/00/20/99/VMD_publiskais_parsk_2005.pdf (accessed on 10 February 2020). (In Latvian)

45. Soil Fields. Available online: https://geolatvija.lv/geo/p/317 (accessed on 10 February 2020). (In Latvian).

46. Kennedy, F. The identification of soils for forest management. In Forestry Commission Field Guide; Forestry Commission: Edinburgh, Scotland, 2002; p. 56.

47. Quine, C.P. Estimation of mean wind climate and probability of strong winds for wind risk assessment. Forestry 2000, 73, 247-258. [CrossRef] 
48. Donis, J.; Šnepsts, G. Novēloti koptu vienvecuma eglu audžu apsaimniekošanas alternatīvas un to ekonomisks izvērtējums. In Economic Evaluation of Alternatives to the Management of Late-Tended Even-Aged Spruce Stands; Jansons, J., Ed.; Vienvecuma egḷ meži Latvijā [Even-Aged Spruce Forests in Latvia]: Salaspils, Latvia, 2019; pp. 71-98. (In Latvian)

49. Krisans, O.; Matisons, R.; Rust, S.; Burnevica, N.; Bruna, L.; Elferts, D.; Kalvane, L.; Jansons, A. Presence of root rot reduces stability of Norway spruce (Picea abies): Results of static pulling tests in Latvia. Forests 2020, 11, 416. [CrossRef]

50. Krisans, O.; Saleniece, R.; Rust, S.; Elferts, D.; Kapostins, R.; Jansons, A.; Matisons, R. Effect of bark-stripping on mechanical stability of Norway spruce. Forests 2020, 11, 357. [CrossRef]

51. Krisans, O.; Samariks, V.; Jansons, A. Root-plate characteristics of Norway spruce in hemiboreal forests. (manuscript in preparation).

52. Ozolinš, R. Forest stand assortment structure analysis using mathematical modelling. For. Stud. 2002, 7, 33-42. [CrossRef]

53. Donis, J. Improved site index scales for most common tree species in Latvia. In Četri Mežzinātnes Motīvi; Jansons, J., Ed.; Saule: Daugavpils, Latvia, 2014; pp. 11-35. (In Latvian)

54. Central Statistical Bureau of Latvia. Forestry Report 2018. Available online: https://www.csb.gov.lv/lv/ statistika/statistikas-temas/lauksaimnieciba/mezsaimnieciba/meklet-tema/386-mezsaimnieciba-2018-gada (accessed on 3 February 2020). (In Latvian)

55. National Energy and Climate Plan 2021-2030. Available online: https:/em.gov.lv/lv/nozares_politika/ nacionalais_energetikas_un_klimata_plans/ (accessed on 23 March 2020).

56. Seidl, R.; Schelhaas, M.J.; Rammer, W.; Verkerk, P.J. Increasing forest disturbances in Europe and their impact on carbon storage. Nat. Clim. Chang. 2014, 4, 806-810. [CrossRef]

57. State Forest Service. Publiskais Pārskats; 2018 Annual Report. Available online: https://www.zm. gov.lv/public/files/CMS_Static_Page_Doc/00/00/01/54/24/VMD_Publiskais_parskats_2018_.pdf (accessed on 20 February 2020). (In Latvian)

58. Fahlvik, N. Aspects of Precommercial Thinning in Heterogeneous Forest in Southern Sweden. Ph.D. Dissertation, Swedish University of Agricultural Sciences, Alnarp, Sweden, 2005.

59. Peltola, H.; Kellomäki, S.; Väisänen, H.; Ikonen, V.-P. A mechanistic model for assessing the risk of wind and snow damage to single trees and stands of Scots pine, Norway spruce, and birch. Can. J. For. Res. 1999, 29, 647-661. [CrossRef]

60. Cameron, A.D. Importance of early selective thinning in the development of long-term stand stability and improved log quality: A review. Forestry 2002, 75, 25-35. [CrossRef]

61. Forest Europe. UNECE and FAO. State of Europe's Forests. In Status and Trends in Sustainable Forest Management in Europe, Proceedings of the Ministerial Conference on the Protection of Forests in Europe, 15 December 2015; Forest Europe, Liaison Unit Madrid: Madrid, Spain, 2015.

62. Valuable Forests of the Future Grow in LSF Nurseries. Available online: https://www.lvm.lv/jaunumi/4377lvm-kokaudzetavas-aug-vertigais-nakotnes-mezs (accessed on 23 March 2020). (In Latvian).

63. Gardiner, B.A.; Quine, C.P. The Mechanical adaptation of trees to environmental influences. In Proceedings of the 3rd Plant Biomechanics Conference, Freiburg, Germany, 27 August-2 September 2000; pp. 71-82.

64. Schütz, J.P.; Götz, M.; Schmid, W.; Mandallaz, D. Vulnerability of spruce (Picea abies) and beech (Fagus sylvatica) forest stands to storms and consequences for Silviculture. Eur. J. For. Res. 2006, 125, 291-302. [CrossRef]

65. Greiss, V.C.; Acevedo, R.; Härtl, F.; Staupendahl, K.; Knoke, T. Does mixing tree species enhance stand resistance against natural hazards? A case study for spruce. For. Ecol. Manag. 2012, 276, 284-296. [CrossRef]

66. Snepsts, G.; Kitenberga, M.; Elferts, D.; Donis, J.; Jansons, A. Stem damage modifies the impact of wind on Norway spruces. Forests 2020, 11, 463. [CrossRef]

(C) 2020 by the authors. Licensee MDPI, Basel, Switzerland. This article is an open access article distributed under the terms and conditions of the Creative Commons Attribution (CC BY) license (http://creativecommons.org/licenses/by/4.0/). 